\title{
Порушення регуляторних механізмів серцевої діяльності при етаноловому пошкодженні печінки у щурів із різною емоційністю
}

\begin{abstract}
Мета роботи: встановити особливості регуляції серцево-судинної системи автономною нервовою системою при етаноловому пошкодженні печінки у високо- і низькоемоційних щурів-самців.

Матеріали і методи. Досліди виконано на 192 білих безпородних високо- і низькоемоційних щурах-самцях (ВЕ і НЕ). Емоційність щурів визначали за методом “відкрите поле”. Усіх щурів поділили на групи: контроль, глюкоза 7 днів, етаноловий гепатит (ЕГ); глюкоза 67 днів, етаноловий гепатоз (Гз), етаноловий фіброз (ЕФ), етаноловий цироз (ЕЦ). Оцінювали стан центральної гемодинаміки, автономної регуляції серцевим ритмом, морфологічні зміни у серці.

Результати досліджень та їх обговорення. Етанолове пошкодження призвело до порушення автономної регуляції серцевого ритму, гемодинаміки та морфологічних змін, що залежало від модельованої патології та емоційності щурів. ЕГ спричинив збільшення варіаційного розмаху, змін кровонаповнення, периферійного опору судин, що більше виражено у ВЕ. У ВЕ при ЕГз зросла мода, зменшилася амплітуда моди, при ЕФ та ЕЦ зменшилася мода, вираженіші морфологічні зміни. У НЕ при ЕГз зросла мода, при ЕФ зменшився варіаційний розмах, були більше виражені компенсаторні гемодинамічні зміни.

Етанолове пошкодження організму щурів призводить до порушення автономної регуляції серцевого ритму та гемодинаміки. Гострий етаноловий гепатит призводить до активації вагусних впливів на серцеву діяльність, порушення кровонаповнення, підвищується периферійний опір судин. Дисфункціональні зміни центральної гемодинаміки та морфологічні зміни вираженіші у ВЕ тварин. При етаноловому гепатозі зменшуються симпатичні регуляторні впливи на серце. При етаноловому фіброзі та цирозі печінки у ВЕ щурів зростають симпатичні впливи, при фіброзі у НЕ зменшуються вагусні впливи. При цьому компенсаторні гемодинамічні зміни більше виражені у НЕ, а морфологічні - у ВЕ.
\end{abstract}

Ключові слова: етанол; гепатит; гепатоз; фіброз; цироз; серце; щури; автономна нервова система; центральна гемодинаміка.

Постановка проблеми і аналіз останніх досліджень та публікацій. Вживання алкоголю $є$ важливою соціальною проблемою, провідним фактором ризику смерті в Європі, оскільки може викликати більше 200 станів, у тому числі хронічні захворювання. Алкогольна хвороба печінки спричинює пошкодження печінки від стеатозу до стеатогепатозу, фіброзу, цирозу і раку печінки [1, $2,3]$. При цьому найбільше пошкодження виникають в серці, печінці, легенях [4]. Надмірне вживання алкоголю асоціюється з підвищеним ризиком таких серцево-судинних захворювань, як алкогольна кардіоміопатія, артеріальна гіпертензія, аритмії передсердь, інсульт $[4,5]$. Порушення гемодинаміки зумовлене регуляторними механізмами, зокрема дисбалансом автономної регуляції. У літературі є поодинокі джерела стосовно аналізу даної проблеми. Так, при розвитку цирозу печінки вірусної етіології у людей встановлено зростання симпатичних впливів центрального походження, зменшення парасимпатичної регуляції, напруженості регуляторних механізмів. Збільшення вагусних впливів погіршує перебіг цирозу і є предиктором летального наслідку [6].

У популяції є люди з різною реактивністю, що залежить як від швидкості метаболічних процесів, так і психологічних особливостей особи. Зв'язок між психікою та соматикою є взаємозалежним [7].
Тому вивчення порушень механізмів регуляції кардіогемодинаміки в особин 3 різною реактивністю є актуальним.

Мета роботи: встановити особливості регуляції серцево-судинної системи автономною нервовою системою при етаноловому пошкодженні печінки у високо- і низькоемоційних щурів-самців.

Матеріали і методи. Досліди виконано на 192 білих безпородних високо- і низькоемоційних щурах-самцях (BE і НЕ). В експерименті використано тварини віком 3 місяці (усього методом “відкрите поле” протестовано 360 тварин).

Емоційність щурів визначали за методом “відкрите поле ” впродовж 10 хвилин. До ВЕ тварин ми віднесли тих, в яких була висока горизонтальна і вертикальна активність, інтенсивне дослідження отворів у днищі тестової камери (нірок), нечасті завмирання. I навпаки, до НЕ віднесли тих, у яких була низька рухова активність, багато завмирань і зростання їх тривалості, уникання тваринами центральних квадратів свідчить про високий рівень тривожності. Тварин тестували двічі з інтервалом 14 днів. Відбирали для подальших досліджень щурів, які двічі підтвердили належність до високо- чи низькоемоційних, до моделювання патології мало пройти не менше 14 днів [8]. 
Усіх щурів поділили на такі групи: контроль (К), глюкоза 7 днів (Гл7), гострий етаноловий гепатит (ЕГ) - ці групи щурів були 4 місячного віку; контроль (К), глюкоза 67 днів (Гл67), етаноловий гепатоз (Гз), етаноловий фіброз (ЕФ), етаноловий цироз (ЕЦ) - ці щури були віком 5,5-6,5 місяці.

Щурів групи контроль утримували в стандартних умовах віварію при вільному доступі до води та їжі.

Тварини групи Гл7 перебували в стандартних умовах віварію при вільному доступі до їжі, але замість води для пиття отримували $5 \%$ розчин глюкози. Для моделювання ЕГ експериментальним тваринам вводили інтрагастрально 12,5 мл/кг $40 \%$ розчину етанолу на 5 \% глюкозі впродовж7 днів. Щури перебували в стандартних умовах віварію при вільному доступі до води та їжі [9].

Тварини групи Гл67 перебували в стандартних умовах віварію при вільному доступі до їжі, але замість води для пиття давали $5 \%$ розчин глюкози. Для моделювання ЕГз щурам впродовж 60 днів давали $10 \%$ розчин етанолу на $5 \%$ розчині глюкози як єдине джерело пиття (попередньо провівши звикання до етанолу 5 \% розчином етанолу на 5 \% розчині глюкозі впродовж 7 днів). Щури перебували в стандартних умовах віварію при вільному доступі до їжі [10]. Для моделювання ЕФ та ЕЦ попередньо проводили адаптацію до алкоголю: в перший тиждень тварини отримували в поїлках замість води 5 \% розчин етанолу, розведений на $5 \%$ розчині глюкози, на другий тиждень - $15 \%$ розчин етанолу розведений $5 \%$ розчином глюкози без обмежень в їжі. 3 початку третього тижня була інтенсивна алкоголізація 96 \% розчином етанолу на шматочку білого хліба впродовж 12 тижнів 14 г/кг (для ЕФ) та 18 г/кг ваги (для ЕЦ) без обмежень у воді. Двічі на тиждень тваринам давали овес $[11,12]$. Усім тваринам робили гістологічне дослідження печінки для підтвердження модельованої патології, також провели забір серця для морфологічного дослідження з забарвленням препаратів гематоксилін-еозином.

Усі експерименти проводили в першій половині дня в спеціально відведеному приміщенні при температурі $18-22{ }^{\circ} \mathrm{C}$, відносній вологості 4060 \% і освітленості 250 лк. Досліди виконано з дотриманням норм Конвенції Ради Європи про захист хребетних тварин, що використовуються для досліджень та інших наукових цілей (Страсбург, 18.03.1986 р.), ухвали Першого національного конгресу з біоетики (Київ, 2001) і наказу МОЗ України № 690 від 23.09.2009 р.

Для дослідження варіабельності серцевого ритму було використано метод варіаційної кардіо- інтервалометрії [13], який дає можливість кількісно оцінити баланс активності холінергічної та адренергічної ланок автономної нервової системи в регуляції синусового вузла та визначити стан регуляторних систем. Для реєстрації також використовували пристрій “Кардіолаб” (Харків, Україна). Проводили запис 1000 послідовно розташованих кардіоінтервалів R-R, розрахунок частоти серцевих скорочень (ЧСС); варіаційного розмаху кардіоінтервалів (Вар); моди; амплітуди моди (AMo); індексу напруження (IH); індексу вегетативної рівноваги (IBP); вегетативного показника ритму (ВПР); показника адекватності процесів регуляції (ПАПР).

Центральну гемодинаміку оцінювали методом інтегральної реографії тіла $[14,15]$. Використовували кардіокомплекс “CardioLab+” (ХАИ-МЕДИKA, м. Харків, Україна). За отриманими результатами розраховували реографічний систолічний індекс (PCI), що відображає інтенсивність пульсового кровонаповнення досліджуваної ділянки, дикротичний індекс (ДКІ), що характеризує периферійний опір артеріальних судин; реографічний діастолічний індекс (РДІ), який відображає інтенсивність венозного відтоку; коефіцієнт інтегральної тонічності (KIT), що свідчить про сумарний артеріальний імпеданс, системний артеріальний тонус. Розраховували ударний об'єм (УО), хвилинний об'єм крові (ХОК), визначали частоту дихання (ЧД).

Статистичну обробку цифрових даних виконано за допомогою програмного забезпечення "Excel " ("Microsoft ”, США) та "STATISTICA" 6.0 (“Statsoft ”, США).

Результати досліджень та їх обговорення. При аналізі кардіоінтервалограм щурів 4-місячного віку встановлено, що досліджувані показники автономного балансу серцевого ритму значно не залежали від емоційності тварин (табл. 1). Семиденне вживання глюкози призвело до збільшення ЧСС і зменшення моди у ВЕ і НЕ тварин, що вказувало на збільшення виділення катехоламінів наднирковими залозами. Також у ВЕ щурів збільшився IН (на 44,4 \%, р<0.05) і ВПР (на 47,9 \%, $\mathrm{p}<0.001)$. Виявилася різниця у показниках між BE i HЕ щурами. Так, у НЕ переважали парасимпатичні впливи на серце, що проявлялося у значно вищих значеннях Вар, менших IH, IBP, ВПР. Очевидно, що глюкоза покращувала метаболічні процеси в обидвох групах тварин, але за різними механізмами. У ВЕ вона полегшувала утворення енергії для забезпечення рухової активності, а у НЕ за рахунок переважання парасимпатичних впливів на організм зменшувалася потреба в оксигені. 
Таблиця 1. Автономна регуляція серцевого ритму у високо- та низькоемоційних щурів при розвитку етанолового гепатиту, $\mathrm{M} \pm \mathrm{m}, \mathrm{n}=12$

\begin{tabular}{|c|c|c|}
\hline \multirow{2}{*}{ Показник } & \multicolumn{2}{|c|}{ Група тварин } \\
\hline & високоемоційні & низькоемоційні \\
\hline \multicolumn{3}{|c|}{ Контроль } \\
\hline Мода, с & $0,137 \pm 0,004$ & $0,130 \pm 0,003$ \\
\hline Амплітуда моди, \% & $43,08 \pm 2,35$ & $41,92 \pm 2,01$ \\
\hline Варіаційний розмах, $10^{-2}$, с & $0,35 \pm 0,02$ & $0,36 \pm 0,02$ \\
\hline ЧСС, $\mathrm{xB}^{-1}$ & $441,17 \pm 13,33$ & $463,67 \pm 9,05$ \\
\hline IH, x103 ум. од. & $48,62 \pm 5,46$ & $46,45 \pm 3,40$ \\
\hline IBP, ум. од. & $12,96 \pm 1,21$ & $12,01 \pm 0,86$ \\
\hline ВПР, ум. од. & $2,18 \pm 0,14$ & $2,20 \pm 0,10$ \\
\hline ПАПР, ум. од. & $0,49 \pm 0,17$ & $0,32 \pm 0,02$ \\
\hline \multicolumn{3}{|c|}{ Глюкоза, 7 днів } \\
\hline Мода, с & $0,116 \pm 0,001^{*}$ & $0,118 \pm 0,003^{*}$ \\
\hline Амплітуда моди, \% & $42,50 \pm 1,66$ & $37,750 \pm 2,25$ \\
\hline Варіаційний розмах, $10^{-2}$, с & $0,29 \pm 0,03$ & $0,38 \pm 0,02^{* *}$ \\
\hline ЧСС, $\mathrm{xB}^{-1}$ & $515,83 \pm 5,26^{*}$ & $512,83 \pm 13,89^{*}$ \\
\hline IH, х10³ ум. од. & $70,22 \pm 7,63^{*}$ & $44,08 \pm 4,72^{* *}$ \\
\hline ІВР, ум. од. & $16,49 \pm 1,91$ & $10,21 \pm 0,95^{* *}$ \\
\hline ВПР, ум. од. & $3,22 \pm 0,26^{*}$ & $2,28 \pm 0,14^{* *}$ \\
\hline ПАПР, ум. од. & $0,36 \pm 0,01$ & $0,32 \pm 0,02$ \\
\hline \multicolumn{3}{|c|}{ Етаноловий гепатит } \\
\hline Мода, с & $0,121 \pm 0,002^{*}$ & $0,132 \pm 0,004^{* *, \#}$ \\
\hline Амплітуда моди, \% & $41,00 \pm 4,03$ & $39,10 \pm 2,81$ \\
\hline Варіаційний розмах, $10^{-2}$, с & $0,48 \pm 0,03^{*}, \#$ & $0,44 \pm 0,03^{*}$ \\
\hline ЧСС, $\mathrm{xB}^{-1}$ & $496,58 \pm 9,28^{*}$ & $458,67 \pm 14,08^{* *, \#}$ \\
\hline IH, x103 ум. од. & $39,50 \pm 7,60^{\#}$ & $37,48 \pm 6,06$ \\
\hline IBP, ум. од. & $9,46 \pm 1,69^{\#}$ & $9,56 \pm 1,34$ \\
\hline ВПР, ум. од. & $1,80 \pm 0,13^{\#}$ & $1,82 \pm 0,16^{*}, \#$ \\
\hline ПАПР, ум. од. & $0,34 \pm 0,04$ & $0,30 \pm 0,03$ \\
\hline
\end{tabular}

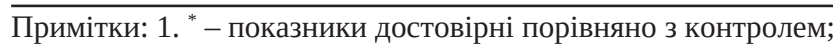
2. ** - показники достовірні порівняно з ВЕ;
3. " - показники достовірні порівняно з глюкозою.

ЕГ у ВЕ і НЕ тварин супроводжувався збільшенням Вар. Таке переважання парасимпатичних впливів, що можна розцінити як тяжкий перебіг ЕГ, що свідчить про астенізацію адаптаційно-ком- пенсаторних механізмів [16, 17]. У ВЕ компенсаторно зменшувалася мода. У НЕ, порівняно з ВЕ, переважала мода і була менша ЧСС, які не відрізнялися від контрольних значень. Такі механізми 
компенсації забезпечували 100 \% виживання тварин при ЕГ.

У дорослих ВЕ тварин, порівняно з НЕ, була достовірно вища мода і менша ЧСС, що вказує на переважання симпатичних впливів у НЕ (табл. 2). Споживання глюкози впродовж 67 днів, як і їі 7-денне вживання, спричинило зростання симпа- тичних впливів у ВЕ. Такі результати можуть вказувати на покращення енергетичного забезпечення організму, оскільки зростала АМо, тобто виділення норадреналіну нервовими терміналями, що спричиняло підвишену потребу в енергії АТФ. У НЕ щурів, навпаки, знизився тонус симпатичної нервової системи (підвищилася мода, знизилася ЧСС).

Таблиця 2. Автономна регуляція серцевого ритму у високо- та низькоемоційних щурів при розвитку етанолового пошкодження печінки, $\mathrm{M} \pm \mathrm{m}, \mathrm{n}=12$

\begin{tabular}{|c|c|c|}
\hline \multirow{2}{*}{ Показник } & \multicolumn{2}{|c|}{ Група тварин } \\
\hline & високоемоційні & низькоемоційні \\
\hline 1 & 2 & 3 \\
\hline \multicolumn{3}{|c|}{ Контроль } \\
\hline Мода, с & $0,133 \pm 0,001$ & $0,121 \pm 0,001^{* *}$ \\
\hline Амплітуда моди, \% & $40,83 \pm 2,76$ & $41,18 \pm 3,48$ \\
\hline Варіаційний розмах, $10^{-2}$, с & $0,38 \pm 0,03$ & $0,45 \pm 0,05$ \\
\hline ЧСС, $\mathrm{xB}^{-1}$ & $450,08 \pm 3,81$ & $498,08 \pm 5,34^{* *}$ \\
\hline $\mathrm{IH}, \mathrm{x} 10^{3}$ ум. од. & $45,41 \pm 6,24$ & $42,74 \pm 5,42$ \\
\hline ІВР, ум. од. & $12,10 \pm 1,66$ & $10,19 \pm 1,23$ \\
\hline ВПР, ум. од. & $2,14 \pm 0,20$ & $1,99 \pm 0,16$ \\
\hline ПАПР, ум. од. & $0,31 \pm 0,021$ & $0,34 \pm 0,03$ \\
\hline \multicolumn{3}{|c|}{ Глюкоза, 67 днів } \\
\hline Мода, с & $0,126 \pm 0,003^{*}$ & $0,126 \pm 0,001^{*}$ \\
\hline Амплітуда моди, \% & $49,67 \pm 1,61^{*}$ & $41,82 \pm 3,21^{* *}$ \\
\hline Варіаційний розмах, $10^{-2}$, с & $0,31 \pm 0,02$ & $0,46 \pm 0,06^{* *}$ \\
\hline ЧСС, $\mathrm{xB}^{-1}$ & $477,33 \pm 10,32^{*}$ & $477,33 \pm 4,90^{*}$ \\
\hline $\mathrm{IH}, \mathrm{x} 10^{3}$ ум. од. & $68,06 \pm 5,48^{*}$ & $43,00 \pm 6,68^{* *}$ \\
\hline IBР, ум. од. & $17,18 \pm 1,42^{*}$ & $10,93 \pm 1,51$ \\
\hline ВПР, ум. од. & $2,76 \pm 0,24$ & $1,95 \pm 0,20^{* *}$ \\
\hline ПАПР, ум. од. & $0,39 \pm 0,01^{*}$ & $0,33 \pm 0,02^{* *}$ \\
\hline \multicolumn{3}{|c|}{ Етаноловий гепатоз } \\
\hline Мода, с & $0,143 \pm 0,004^{*}, \#$ & $0,141 \pm 0,004^{*, \#}$ \\
\hline Амплітуда моди, \% & $32,50 \pm 2,38^{*, \#}$ & $34,50 \pm 2,70$ \\
\hline Варіаційний розмах, $10^{-2}$, с & $0,49 \pm 0,04^{\#}$ & $0,47 \pm 0,04^{\#}$ \\
\hline ЧСС, $\mathrm{xB}^{-1}$ & $420,50 \pm 12,79^{*}, \#$ & $427,92 \pm 11,77^{*}, \#$ \\
\hline IH, x10³ ум. од. & $29,53 \pm 6,54^{\#}$ & $29,70 \pm 4,45$ \\
\hline IBР, ум. од. & $8,09 \pm 1,63^{\#}$ & $8,35 \pm 1,19$ \\
\hline ВПР, ум. од. & $1,66 \pm 0,25^{\#}$ & $1,63 \pm 0,13$ \\
\hline ПАПР, ум. од. & $0,23 \pm 0,02^{*, \#}$ & $0,24 \pm 0,02^{*}, \#$ \\
\hline
\end{tabular}


Продовження табл. 2.

\begin{tabular}{|c|c|c|}
\hline 1 & 2 & 3 \\
\hline \multicolumn{3}{|c|}{ Етаноловий фіброз } \\
\hline Мода, с & $0,122 \pm 0,000^{*}, \# \#$ & $0,124 \pm 0,002^{\# \#}$ \\
\hline Амплітуда моди, \% & $32,83 \pm 2,69^{\#}$ & $38,58 \pm 1,42$ \\
\hline Варіаційний розмах, $10^{-2}$, с & $0,39 \pm 0,02^{\#}$ & 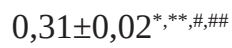 \\
\hline ЧСС, $\mathrm{xB}^{-1}$ & $491,42 \pm 0,48^{*}$ & $483,75 \pm 7,41^{\# \#}$ \\
\hline IH, x10³ ум. од. & $43,18 \pm 4,41^{\#}$ & $54,91 \pm 5,66^{\# \#}$ \\
\hline IBP, ум. од. & $10,53 \pm 1,08^{\#}$ & $13,59 \pm 1,38^{\# \#}$ \\
\hline ВПР, ум. од. & $2,17 \pm 0,13^{\#}$ & 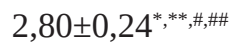 \\
\hline ПАПР, ум. од. & $0,32 \pm 0,02^{\#, \# \#}$ & $0,31 \pm 0,01^{\# \#}$ \\
\hline \multicolumn{3}{|c|}{ Етаноловий цироз } \\
\hline Мода, с & $0,124 \pm 0,001^{*, \#}$ & $0,124 \pm 0,003^{\# \#}$ \\
\hline Амплітуда моди, \% & $34,75 \pm 2,81^{\#}$ & $39,83 \pm 1,33$ \\
\hline Варіаційний розмах, $10^{-2}$, с & $0,48 \pm 0,07^{\#}$ & $0,42 \pm 0,02^{\#, * * *}$ \\
\hline ЧСС, $\mathrm{XB}^{-1}$ & $484,25 \pm 4,96^{*}, \# \#$ & $485,42 \pm 9,21^{\# \#}$ \\
\hline IH, x10³ ум. од. & $42,89 \pm 9,17^{\#}$ & $39,86 \pm 2,57^{* * *}$ \\
\hline IBP, ум. од. & $10,41 \pm 2,15^{\#}$ & $9,89 \pm 0,69^{* * *}$ \\
\hline ВПР, ум. од. & $2,19 \pm 0,34$ & $1,97 \pm 0,08^{\# \#, * * *}$ \\
\hline ПАПР, ум. од. & $0,28 \pm 0,03^{\#}$ & $0,32 \pm 0,01^{\# \#}$ \\
\hline
\end{tabular}

Примітки: $1 .{ }^{*}$ - показники достовірні порівняно з контролем;
2. ${ }^{* *}$ - показники достовірні порівняно з ВE;
3. " - показники достовірні порівняно з глюкозою;
4. - показники достовірні порівняно з гепатозом;
5. ${ }^{* * *}$ - показники достовірні порівняно з фіброзом.

При ЕГз, порівняно з контролем, i у ВЕ і у НЕ зросла Мо, зменшилися ЧСС і ПАПР. У ВЕ тварин зменшилася також АМо. Таке зменшення симпатичної регуляції можна розцінити як наслідок руйнування гепатоцитів і практично різниці у досліджуваних показниках не виявлено.

При ЕФ у ВЕ зменшилася мода на 8,4 \% ( $<<0,001)$, зросла ЧСС на 9,2\% (p<0,001), а у НЕ - знизився Вар на $31,5 \%(p<0,01)$ і збільшилася ВПР на 40,3 \% (p<0,05). Таке зростання симпатичної регуляції, яке відбувається за різними механізмами (у ВЕ збільшення виділення адреналіну мозковим шаром надниркових залоз, а у НЕ - зменшення парасимпатичних регуляторних впливів), можна розцінювати як обмеження тяжкості патологічного процесу в організмі щурів або адекватне пристосування до нього. Причому за механізмом компенсації можна думати, що у ВЕ перебіг
ЕФ був легшим, оскільки адаптація була на периферичному рівні.

При ЕЦ у ВЕ зменшилася мода на 6,5 \% ( $<<0,001)$, зросла ЧСС на 7,6 \% ( $<<0,001)$, а у НЕ значення не відрізнялися від контрольних. До того ж, як і при ЕФ, при ЕЦ зникала різниця між показниками BE i HE щурів.

Зміни показників центральної гемодинаміки при ЕГ наведено в таблиці 3. PCI у ВЕ достовірно знизився, РДІ зросла, ДКІ збільшився, а КІТ зменшився. Зросли також значення ЧД, ЧСС. Такі результати можна оцінити як втягнення в патологічний процес ендотелію судин, нирок, легень, а не тільки печінки і серця. У НЕ щурів порівняно 3 контролем, збільшився ДКІ, що також характеризує порушення функції ендотелію судин і вказує на менше пошкодження, порівняно з ВЕ тваринами. Вживання глюкози у ВЕ сприяє посиленню кро- 
Таблиця 3. Показники інтегральної реографії тіла у високо- та низькоемоційних щурів при розвитку етанолового гепатиту, $\mathrm{M} \pm \mathrm{m}, \mathrm{n}=12$

\begin{tabular}{|c|c|c|}
\hline \multirow{2}{*}{ Показник } & \multicolumn{2}{|c|}{ Група тварин } \\
\hline & високоемоційні & низькоемоційні \\
\hline \multicolumn{3}{|c|}{ Контроль } \\
\hline PCI, Ом & $0,589 \pm 0,043$ & $0,667 \pm 0,080$ \\
\hline ДКІ, \% & $63,49 \pm 2,51$ & $61,46 \pm 3,314$ \\
\hline РДІ, \% & $74,22 \pm 2,55$ & $71,77 \pm 3,16$ \\
\hline КIT, ум. од. & $288,46 \pm 8,34$ & $276,93 \pm 7,00$ \\
\hline УО, мкл & $51,72 \pm 4,25$ & $67,21 \pm 10,47$ \\
\hline ЧД, хв.-1 & $91,78 \pm 6,13$ & $112,29 \pm 4,62^{* *}$ \\
\hline ЧСС, хв. ${ }^{-1}$ & $412,52 \pm 15,19$ & $426,99 \pm 13,77$ \\
\hline ХОК, мл/хв & $21,25 \pm 1,88$ & $27,57 \pm 3,73$ \\
\hline \multicolumn{3}{|c|}{ Глюкоза, 7 днів } \\
\hline PCI, Ом & $0,536 \pm 0,019$ & $0,397 \pm 0,022^{*, * *}$ \\
\hline ДКІ, \% & $62,49 \pm 1,34$ & $57,85 \pm 1,83^{* *}$ \\
\hline РДІ, \% & $73,22 \pm 1,89$ & $74,67 \pm 2,63$ \\
\hline КIT, ум. од. & $267,63 \pm 6,77$ & $320,56 \pm 13,48^{* . * *}$ \\
\hline УО, мкл & $70,51 \pm 3,44^{*}$ & $37,25 \pm 1,33^{* * * *}$ \\
\hline ЧД, хв.-1 & $130,79 \pm 7,51$ & $119,82 \pm 3,76$ \\
\hline ЧСС, хв. ${ }^{-1}$ & $448,72 \pm 21,21$ & $517,54 \pm 15,42^{* . * *}$ \\
\hline ХОК, мл/хв & $31,73 \pm 2,39^{*}$ & $19,20 \pm 0,69^{* . * *}$ \\
\hline \multicolumn{3}{|c|}{ Етаноловий гепатит } \\
\hline PCI, Ом & $0,418 \pm 0,030^{* . \#}$ & $0,547 \pm 0,025^{* * . \#}$ \\
\hline ДКІ, \% & $74,52 \pm 3,28^{*} . \#$ & $71,01 \pm 1,45^{* . \#}$ \\
\hline РДІ, \% & $81,12 \pm 2,31^{* . \#}$ & $75,37 \pm 2,15$ \\
\hline КIT, ум. од. & $237,91 \pm 11,07^{* . \#}$ & $265,77 \pm 7,43^{\#}$ \\
\hline УО, мкЛ & $56,22 \pm 5,49^{\#}$ & $64,32 \pm 3,55^{\#}$ \\
\hline ЧД, $\mathrm{xB}^{-1}$ & $163,49 \pm 31,19^{*}$ & $113,98 \pm 4,76$ \\
\hline ЧСС, хв..$^{-1}$ & $492,66 \pm 23,43^{*}$ & $446,96 \pm 13,13^{\#}$ \\
\hline ХОК, мл/хв & $26,62 \pm 2,10$ & $28,41 \pm 1,25^{\#}$ \\
\hline
\end{tabular}

Примітки: 1. * - показники достовірні порівняно з контролем;

2. ** - показники достовірні порівняно з ВЕ;

3. " - показники достовірні порівняно з глюкозою.

вообігу за рахунок позитивного інотропного ефекту. У НЕ вживання глюкози, навпаки, спричинює зменшення кровообігу, кровонаповнення органів, розвиток позитивного хронотропного і негативного інотропного ефекту, зростання тонусу артерій.
Зміни показників центральної гемодинаміки при хронічному етаноловому пошкодженні печінки наведена в таблиці 4. У дорослих НЕ тварин, порівняно з ВЕ, як і в молодих щурів, зареєстровано більшу ЧД, а також у дорослих НЕ щу- 
Таблиця 4. Показники інтегральної реографії тіла у високо- та низькоемоційних щурів при розвитку етанолового пошкодження печінки, $\mathrm{M} \pm \mathrm{m}, \mathrm{n}=12$

\begin{tabular}{|c|c|c|}
\hline \multirow{2}{*}{ Показник } & \multicolumn{2}{|c|}{ Група тварин } \\
\hline & високоемоційні & низькоемоційні \\
\hline 1 & 2 & 3 \\
\hline \multicolumn{3}{|c|}{ Контроль } \\
\hline PCI, Ом & $0,522 \pm 0,032$ & $0,496 \pm 0,039$ \\
\hline ДКІ, \% & $69,40 \pm 2,10$ & $74,31 \pm 2,01$ \\
\hline РДІ, \% & $81,63 \pm 1,71$ & $82,93 \pm 1,89$ \\
\hline КIT, ум. од. & $295,44 \pm 8,90$ & $281,48 \pm 8,85$ \\
\hline УО, мкл & $54,02 \pm 6,73$ & $55,69 \pm 5,01$ \\
\hline ЧД, хв.-1 & $113,07 \pm 2,87$ & $153,02 \pm 8,09^{* *}$ \\
\hline ЧСС, хв. ${ }^{-1}$ & $430,89 \pm 6,81$ & $455,40 \pm 10,12^{* *}$ \\
\hline ХОК, мл/хв & $23,54 \pm 3,19$ & $25,03 \pm 2,05$ \\
\hline \multicolumn{3}{|c|}{ Глюкоза, 67 днів } \\
\hline PCI, Ом & $0,602 \pm 0,049$ & $0,534 \pm 0,023$ \\
\hline ДКІ, \% & $71,98 \pm 2,94$ & $71,86 \pm 2,03$ \\
\hline РДІ, \% & $79,37 \pm 2,20$ & $81,200 \pm 1,90$ \\
\hline КIT, ум. од. & $282,80 \pm 7,98$ & $273,88 \pm 4,93$ \\
\hline УО, мкл & $65,06 \pm 4,63$ & $67,97 \pm 6,85$ \\
\hline ЧД, хв.-1 & $131,71 \pm 4,17^{*}$ & $123,40 \pm 6,99^{*}$ \\
\hline ЧСС, хв..$^{-1}$ & $459,52 \pm 11,28^{*}$ & $432,97 \pm 7,10$ \\
\hline ХОК, мл/Хв & $29,64 \pm 1,82$ & $29,35 \pm 3,00$ \\
\hline \multicolumn{3}{|c|}{ Етаноловий гепатоз } \\
\hline PCI, OM & $0,448 \pm 0,032^{\#}$ & $0,459 \pm 0,029^{\#}$ \\
\hline ДКІ, \% & $71,67 \pm 1,52$ & $66,34 \pm 1,55^{*, * *, \#}$ \\
\hline РДІ, \% & $78,67 \pm 1,86$ & $73,96 \pm 1,99^{\#}$ \\
\hline КIT, ум. од. & $272,61 \pm 8,21$ & $285,59 \pm 9,27$ \\
\hline УО, мкл & $42,33 \pm 3,14^{\#}$ & $46,01 \pm 3,13^{\#}$ \\
\hline ЧД, хв ${ }^{-1}$ & $103,29 \pm 6,78^{\#}$ & $109,232 \pm 5,973^{*}$ \\
\hline ЧСС, хв. $^{-1}$ & $398,30 \pm 17,94^{\#}$ & $405,78 \pm 8,32^{*}, \#$ \\
\hline ХОК, мл/хв & $16,57 \pm 1,15^{*, \#}$ & $18,59 \pm 1,24^{*, \#}$ \\
\hline \multicolumn{3}{|c|}{ Етаноловий фіброз } \\
\hline PCI, OM & $0,476 \pm 0,029$ & $0,489 \pm 0,024$ \\
\hline ДКІ, \% & $68,49 \pm 2,62$ & $66,74 \pm 2,57^{*}$ \\
\hline РДІ, \% & $77,33 \pm 1,75$ & $75,77 \pm 1,93^{*}, \#$ \\
\hline КIT, ум. од. & $274,42 \pm 9,18$ & $271,07 \pm 10,50$ \\
\hline УО, мкЛ & $56,57 \pm 5,44^{\# \#}$ & $58,06 \pm 3,99^{\# \#}$ \\
\hline
\end{tabular}


Продовження табл. 3

\begin{tabular}{|c|c|c|}
\hline 1 & 2 & 3 \\
\hline ЧД, $\mathrm{xB}^{-1}$ & $113,49 \pm 6,63^{\#}$ & $125,45 \pm 2,57^{*}, \# \#$ \\
\hline ЧСС, хв. $^{-1}$ & $467,55 \pm 7,67^{*}, \# \#$ & $472,61 \pm 8,46^{\#, \# \#}$ \\
\hline ХОК, мл/хв & $26,19 \pm 2,19^{\# \#}$ & $27,28 \pm 1,59^{\# \#}$ \\
\hline \multicolumn{3}{|c|}{ Етаноловий цироз } \\
\hline PCI, Ом & $0,537 \pm 0,048$ & $0,602 \pm 0,033^{*}, \#, * * * *$ \\
\hline ДКІ, \% & $69,39 \pm 2,67$ & $69,59 \pm 1,47$ \\
\hline РДІ, \% & $76,59 \pm 2,67$ & $80,13 \pm 1,74^{\# \#}$ \\
\hline КІT, ум. од. & $290,83 \pm 9,61$ & $267,35 \pm 5,55^{* *}$ \\
\hline УО, мкл & $58,90 \pm 6,57^{\# \#}$ & $73,87 \pm 4,55^{*, \#,, * * *}$ \\
\hline ЧД, $\mathrm{xB}^{-1}$ & $126,37 \pm 4,57^{*}, \# \#$ & $120,79 \pm 4,78^{*}$ \\
\hline ЧСС, Хв..$^{-1}$ & $444,35 \pm 5,10^{\# \#, * * *}$ & $446,14 \pm 14,38^{\# \#}$ \\
\hline ХОК, мл/Хв & $26,12 \pm 2,83^{\# \#}$ & $33,10 \pm 2,44^{*}, \# \#$ \\
\hline
\end{tabular}

Примітки: 1. ${ }^{*}$ - показники достовірні порівняно з контролем;

2. ** - показники достовірні порівняно з ВЕ;

3. " - показники достовірні порівняно з глюкозою;

4. \# - показники достовірні порівняно з гепатозом;

5. ${ }^{* * *}$ - показники достовірні порівняно з фіброзом.

рів більша ЧСС. Вживання глюкози впродовж 67 днів спричинило збільшення ЧД і ЧСС у ВЕ тварин і зменшення ЧД у НЕ.

При ЕГз у ВЕ тварин спостерігали зменшення ХОК, а порівняно з групою, яка вживала 67 днів глюкозу для пиття - встановлено зменшення гемодинаміки, пульсового наповнення судин. При ЕГз у НЕ тварин спостерігали зменшення ХОК, загального перифійного опору судин, ЧСС, а порівняно 3 групою, яка вживала 67 днів глюкозу для пиття зменшення гемодинаміки, пульсового наповнення судин, загального периферійного опору судин.

При ЕФ у ВЕ збільшилася ЧСС, а у НЕ зменшилася інтенсивність венозного відтоку, периферійний опір судин, ЧД.

При ЕЦ збільшилася ЧД, що може вказувати на компенсаторну гіпоксичну реакцію при ураженні легень. У НЕ тварин зросла інтенсивність пульсового кровонаповнення, УО, ХОК, зменшилася ЧД, що вказує на кращі реологічні процеси в НЕ.

При ЕЦ встановлено максимальні зміни у серці тварин. У міокарді ВЕ щурів спостерігали розлади кровообігу із переважанням дилатації судинного русла і стазу крові, морфологічні ознаки ендотеліальної дисфункції - набухання, набряк і злущення ендотеліоцитів. Поряд із ділянками подібних змін ми виявляли зони ішемії, зумовле- ні редукцією мікроциркуляторного русла. В стінках судин різного калібру та периваскулярно мали місце поліморфноклітинні інфільтрати із переважанням активно проліферуючих фібробластів. Кількість колагенових волокон збільшувалася в усіх складових судинних стінок, а проліферуючі колагенові фібрили адвентицію впліталися у фіброзні периваскулярні муфти (рис. 1).

Кардіоміоцити втрачали характерні структурні особливості. Їх контури “розмивалися”, цитоплазма розпадалася на фрагменти різних розмірів, ядра або не візуалізувалися, або знаходилися в оптично порожньому середовищі цитоплазми. Між кардіоміоцитами інтерстицій ущільнювався і потовщувався за рахунок колагенових волокон. Таким чином формувалися ділянки дифузного кардіосклерозу.

У міокарді НЕ щурів на тлі уже перманентних розладів гемодинаміки виявляли ознаки хронізації запальних змін у стінках судин. Запальні інфільтрати змінювали свій клітинний склад, серед лімфоцитів та макрофагів з'являлися фібробласти не тільки поблизу судин, а й у міжклітинних проміжках. Набували поширення ознаки порушення контрактильної здатності серцевих міоцитів - фрагментація, розпад, звивистий хід та хаотичне розміщення з дезорганізацією клітинного пласту, розрізнені дрібні осередки цитолізу (рис. 2). В інших спосте- 


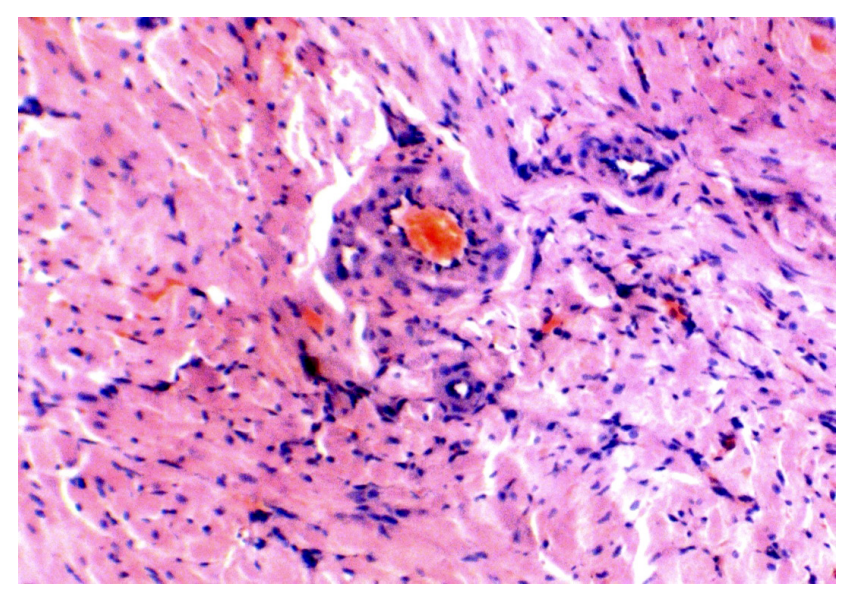

Рис. 1. Фрагмент міокарда ВЕ щура із цирозом печінки. Судини нерівномірно кровонаповнені із товстими склерозованими стінками. Периваскулярний склероз, внутрішньосудинні інфільтрати. Кардіоміоцити розпадаються на фрагменти різних розмірів. Забарвлення гематоксиліном і еозином. ×200.

реженнях пласти кардіоміцитів розмежовувалися товстими прошарками розпушеної набряком та інфільтрованої жировою клітковиною стромою.

Висновки. 1. Етанолове пошкодження організму щурів призводить до порушення автономної регуляції серцевого ритму та гемодинаміки. Гострий етаноловий гепатит призводить до активації вагусних впливів на серцеву діяльність, порушення кровонаповнення, підвищувався периферійний опір судин. Дисфункціональні зміни центральної гемодинаміки та морфологічні зміни вираженіші у ВЕ тварин.

\section{СПИСОК ЛІТЕРАТУРИ}

1. Alcohol associated liver disease 2020: A clinical practice guideline by the Italian Association for the Study of the Liver (AISF) / G. Addolorato, L. Abenavoli, M. Dallio [et al.] // Digestive and Live Disease. - 2020. - Vol. 52, I. 4. - P. 374391.

2. Global, regional, and national comparative risk assessment of 79 behavioural, environmental and occupational, and metabolic risks or clusters of risks in 188 countries, 1990-2013: a systematic analysis for the Global Burden of Disease Study 2013 / M. H. Forouzanfar, L. Alexander, H. R. Anderson [et al.] // Lancet. - 2015. - Vol. 386. - P. 2287-2323.

3. Shield K. D. Chronic diseases and conditions related to alcohol use / K. D. Shield, C. Parry, J. Rehm // Alcohol Res. - 2013. Vol. 35. - P. 155-173.

4. Cardiac manifestations in alcoholic liver disease / S. Milić, D. Lulić, D. Štimac [et al.] // BMJ Journal. - 2016. - Access mode : https://pmj.bmj.com/content/92/1086/235.

5. Ismaiel A. Cardiovascular risk in fatty liver disease: The liverheart axis - literature review / A. Ismaiel, D. L. Dumitraşcu // Front Med. (Lausanne). - 2019. - No 6. - P. 202.

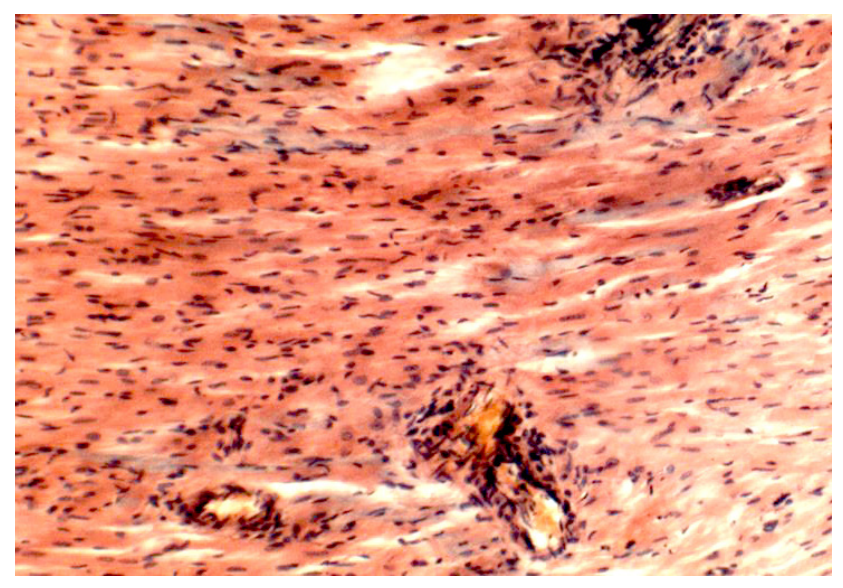

Рис. 2. Фрагмент міокарда НЕ щура із цирозом печінки. Поліморфноклітинні інфільтрати в стінках судин та периваскулярній тканині. Забарвлення гематоксиліном і еозином. ×200.

2. При етаноловому гепатозі зменшуються симпатичні регуляторні впливи на серце. При етаноловому фіброзі та цирозі печінки у ВЕ щурів зростають симпатичні впливи, при фіброзі у НЕ зменшуються вагусні впливи. При всіх змодельованих патологіях компенсаторні гемодинамічні зміни більше виражені у НЕ, а морфологічні - у ВЕ.

Перспективи подальших досліджень. Для встановлення механізмів етанолового пошкодження серцево-судинної системи у тварин із різною емоційністю буде проведено дослідження окисного стресу.

6. Состояние вегетативной нервной системы при циррозе печени вирусной этиологии / Е. Ю. Плотникова, Е. Н. Баранова, М. В. Краснова, К. А. Краснов // Лечащий врач. - 2013. № 2. - C. 38-44.

7. De Hert M. M. De Hert, J. Detraux, D. Vancampfort // Dialogues Clin Neurosci. 2018. 20(1): 31-40.

8. Лукьянова Л. В. Изучение поведенческих реакций при введении кофеина, карбмазепина и их композиций в условиях формалинового отёка у крыс / Л. В. Лукьянова // Український біофармацевтичний журнал. - 2016. - Т. 42, № 1. - С. 22-26. 9. Пат. № 135341 МПК: G 09 В 23/28. Спосіб моделювання гострого етанолового гепатиту у високоемоційних та низькоемоційних щурів-самців / Костюк О. А., Денефіль О. В., Головата Т. К.; опубл. 25.06.2019, Бюл. 12/2019.

10. Пат. № 135342 МПК: G 09 В 23/28. Спосіб моделювання хронічного етанолового гепатозу у високоемоційних та низькоемоційних щурів-самців / Костюк О. А., Денефіль О. В., Головата Т. К.; опубл. 25.06.2019, Бюл. 12/2019.

11. Пат. № 135948 МПК: G 09 В 23/28. Спосіб моделювання етанолового цирозу у високоемоційних та низькоемоційних 
щурів-самців / Костюк О. А., Денефіль О. В., Головата Т. К.; опубл. 25.07.2019, Бюл. 14/2019.

12. Пат. № 135949 МПК: G 09 В 23/28. Спосіб моделювання етанолового фіброзу у високоемоційних та низькоемоційних щурів-самців / Костюк О. А., Денефіль О. В., Головата Т. К.; опубл. 25.07.2019, Бюл. 14/2019.

13. Анализ вариабельности сердечного ритма при использовании различных электрокардиографических систем / Р. М. Баевский, Г. Г. Иванов, Л. В. Чирейкин [и др.] // Вестн. Аритмол. - 2001. - № 24. - С. 65-87.

14. Колесников И. С. Интегральная реография тела как метод оценки состояния системы кровообращения при хирургических заболеваниях / И. С. Колесников, М. И. Лыткин, М. И. Тищенко // Вестник хирургии. - 1981. - № 1. - С. 9-12.
15. Пилипчук В. В. Реовазографічні показники серед осіб із різним рівнем фізичної активності / В. В. Пилипчук // Вісник Волинського державного університету. Серія “Медицина ". 2008. - Вип. 9. - С. 75-76.

16. Динамика клинико-биохимических параметров и функционального состояния вегетативной нервной системы у больных острым гепатитом В с хроническим употреблением алкоголя в гепатотоксических дозах / Е. А. Фурик, Е. В. Рябоконь, Т. Е. Онищенко [и др.] //Запорожский медицинский журнал. - 2014. - № 1 (82). - С. 60-63.

17. Baroreceptor sensitivity and baroreceptor effectiveness index in cirrhosis: the relevance of hepatic venous pressure gradient / S. Genovesi, D. M. Prata Pizzala, M. Pozzi [et al.] // Liver Int. 2010. - Vol. 30. - P. 232-239.

\section{REFERENCES}

1. Addolorato, G., Abenavoli, L., Dallio, M., Loguercio, C., Marra, F., \& Stasi E. (2020). Alcohol associated liver disease 2020: A clinical practice guideline by the Italian Association for the Study of the Liver (AISF). Digestive and Live Disease, 52 (4), 374-391. 2. Forouzanfar, M.H., Alexander, L., Anderson, H.R., Bachman, V.F., Biryukov, S., Brauer, M., et al. (2015). Global, regional, and national comparative risk assessment of 79 behavioural, environmental and occupational, and metabolic risks or clusters of risks in 188 countries, 1990-2013: A systematic analysis for the Global Burden of Disease Study 2013. Lancet, 386, 2287-2323.

3. Shield, K.D., Parry, C., \& Rehm, J. (2013). Chronic diseases and conditions related to alcohol use. Alcohol Res., 35, 155-173. 4. Milić, S., Lulić, D., \& Štimac, D. (2016). Cardiac manifestations in alcoholic liver disease. BMJ Journal. Retrieved from: https://pmj.bmj.com/content/92/1086/235

5. Ismaiel, A., \& Dumitraşcu, D.L. (2019). Cardiovascular risk in fatty liver disease: The liver-heart axis - literature review. Front Med. (Lausanne), 6, 202.

6. Plotnikova, E.Yu., Baranova, E.N., Krasnova, M.V., \& Krasnov, K.A. (2013). Sostoyaniye vegetativnoy nervnoy sistemy pri tsirroze pecheni virusnoy etiologii [The state of the autonomic nervous system in liver cirrhosis of viral etiology]. Lechashchiy vrach - Attending Physician, 2, 38-44 [in Russian].

7. De Hert, M., Detraux, J., \& Vancampfort, D. (2018). Dialogues. Clin. Neurosci., 20 (1), 31-40.

8. Lukyanova, L.V. (2016). Izuchenie povedenchiskich reaktsiy pri vvedenii kofeina, karbamazepina i ikh kompozitsiy v usloviyakh formalinovogo oteka u krys [Study of behavioral reactions with the introduction of caffeine, carbmazepine and their compositions under conditions of formalin edema in rats]. Ukrainskyi biofarmatsevtychnyi zhurnal - Ukrainian Biopharmaceutical Journal, 42 (1), 22-26 [in Russian].

9. Kostyuk, O.A., Denefil, O.V., \& Holovata, T,K. Patent No. 135341 IPC: G 09 B 23/28; [Method for modeling acute ethanol hepatitis in highly emotional and low-emotional male rats]. Sposib moduliuvannia hostroho etanolovoho heptytu u vysokoemotsiinykh ta nuzkoemotsiinykh shchuriv-samtsiv. Published on June 25, 2019, Bull. 12/2019 [in Ukrainian].

10. Kostyuk, O.A., Denefil, O.V., \& Holovata, T.K. Patent No. 135342 IPC: G 09 B 23/28; [Method for modeling chronic ethanol hepatosis in highly emotional and low-emotional male rats]. Sposib moduliuvannia etanolovoho heptozu u vysokoemotsiinykh ta nyzkoemotsiinykh shchuriv-samtsiv. Published on June 25, 2019, Bull. 12/2019 [in Ukrainian].
11. Kostyuk, O.A., Denefil, O.V., \& Holovata, T.K. Patent No. 135948 IPC: G 09 B 23/28; [Method of modeling ethanol cirrhosis in highly emotional and low-emotional male rats]. Sposib moduliuvannia etanolovoho tsyrozu u vysokoemotsiinykh ta nyzkoemotsiinykh shchuriv-samtsiv. Published on July 25, 2019, Bull. 14/2019 [in Ukrainian].

12. Kostyuk, O.A., Denefil, O.V., \& Holovata, T.K. Patent No. 135949 IPC: G 09 B 23/28; [Method of modeling ethanol fibrosis in highly emotional and low-emotional male rats]. Sposib moduliuvannia etanolovoho fibrozu u vysokoemotsiinykh ta nyzkoemotsiinykh shchuriv-samtsiv. Published on July 25, 2019, Bull. 14/2019 [in Ukrainian].

13. Baevskii, R.M., Ivanov, G.G., Chireikin, L.V., \& Gavrilushkin, A.P. (2001). Analiz variabelnosti serdechnogo ritma pri ispolzovanii razlichnykh elektrokardiograficheskikh system [Analysis of heart rate variability in the use of various electrocardiographic systems]. Vestnik Aritmologii - Bulleten of Arrhythmology, 24, 65-87 [in Russian].

14. Kolesnikov, I.S., Lytkin, M.I., \& Tishchenko, M.I. (1981). Integralnaya reografiya tela kak metod otsenki sostoyaniya systemy krovoobrashcheniya pri khirurgicheskikh zabolevaniyakh [Integral rheography of the body as a method of assessing the state of the circulatory system in surgical diseases]. Vestnik khirurgii Bulleten of Surgery, 1981 1, 9-12 [in Russian].

15. Pylypchuk, V.V. (2008). Reovasohrafichni pokaznyky sered osib iz riznym rivnem fizychnoi aktyvnosti [Rheovasographic indicators among people with different levels of physical activity]. Visnyk Volynskoho derzhavnoho universytetu. Seriia MedytsynaBulletin of Volyn State University. Medicine Series, 9, 75-76 [in Ukrainian].

16. Furik, E.A., Ryabokon, E.V., Onishchenko, T.E., Savelyev, V.G., \& Mashko, O.P. (2014). Dinamika kliniko-biokhimicheskikh parametrov i funktsionalnogo sostoyaniya vegatativnoy nervnoy sistemy u bolnykh ostrym gepatitom B s khronicheskim upotrebleniem alkogolya $\mathrm{v}$ gepatotoksicheskikh dozakh [Dynamics of clinical and biochemical parameters and functional state of the autonomic nervous system in patients with acute hepatitis B with chronic alcohol consumption in hepatotoxic doses]. Zaporizkyi medychnyi zhurnal - Zaporizhzhia Medical Journal, 1 (82), 60-63 [in Russian].

17. Genovesi, S., Prata Pizzala, D.M., \& Pozzi, M. (2010). Baroreceptor sensitivity and baroreceptor effectiveness index in cirrhosis: the relevance of hepatic venous pressure gradient. Liver Int., 30, 232-239.

Отримано 09.09.2020 
O. A. KOSTYUK, O. V. DENEFIL, V. E. PELYKH

I. Horbachevsky Ternopil National Medical University

\title{
VIOLATION OF THE REGULATORY MECHANISMS OF CARDIAC ACTIVITY IN ETHANOL LIVER DAMAGE IN RATS WITH DIFFERENT EMOTIONALITY
}

\begin{abstract}
The aim of the work: to establish the features of regulation of the cardiovascular system by the autonomic nervous system in ethanol liver damage in high- and low-emotional male rats.

Materials and Methods. The experiments were performed on 192 white outbred high- and low-emotional male rats (HE and LE). The emotionality of the rats were determined by the method of "open field". All rats were divided into the groups: control, glucose 7 days, ethanol hepatitis (EH); glucose 67 days, ethanol hepatosis (EHs), ethanol fibrosis (EF), ethanol cirrhosis (EC). The state of central hemodynamics, autonomic regulation of heart rhythm, morphological changes in the heart were evaluated.

Results and Discussion. Ethanol damage led to a violation of the autonomic regulation of heart rhythm, hemodynamics and morphological changes, which depended on the simulated pathology and emotionality of the rats. EH led to variational swinging, changes in blood supply, peripheral vascular resistance, which is more pronounced in HE. In HE at EHs the moda increased, the amplitude of moda decreased, at EF and EC the moda decreased, morphological changes were more expressed. In LE at EHs the moda increased, at EF the variational swinging decreased, was more expressed compensatory hemodynamic changes.

Ethanol damage of the body in rats leads to a violation of the autonomic regulation of heart rhythm and hemodynamics. Acute ethanol hepatitis leads to activation of nervus vagus effects on cardiac activity, circulatory disorders, increased of peripheral vascular resistance. Dysfunctional changes in central hemodynamics and morphological changes expressed in HE animals. Ethanol hepatosis reduces sympathetic regulatory effects on the heart. In ethanol fibrosis and cirrhosis of the liver, the sympathetic effects increase in the HE, and in the case of fibrosis in the LE decrease the vagal influences. At the same time compensatory hemodynamic changes more expressed in LE, and morphological - in HE rats.
\end{abstract}

Key words: ethanol; hepatitis; hepatosis; fibrosis; cirrhosis; heart; rats; autonomic nervous system; central hemodynamics.

\section{О. А. КОСТЮК, О. В. ДЕНЕФИЛЬ, В. Е. ПЕЛЫХ}

Тернопольский национальный медицинский университет имени И. Я. Горбачевского МОЗ Украины

\section{НАРУНЕНИЕ РЕГУЛЯТОРНЫХ МЕХАНИЗМОВ СЕРДЕЧНОЙ ДЕЯТЕЛЬНОСТИ ПРИ ЭТАНОЛОВЫХ ПОВРЕЖКДЕНИЯХ ПЕЧЕНИ У КРЫС С РАЗНОЙ ЭМОЦИОНАЛЬНОСТЬЮ}

\begin{abstract}
Цель работы: установить особенности регулирования сердечно-сосудистой системы автономной нервной системой при этаноловом повреждении печени у высоко- и низкоэмоциональных крыс-самцов.

Материалы и методы. Опыты выполнены на 192 белых беспородных высоко- и низькоэмоциональных крысах-самцах (ВЭ и НЭ). Эмоциональность поиска определяются по методу “открытое поле”. Всех крыс разделили на группы: контроль, глюкоза 7 дней, этаноловый гепатит (ЭГ), глюкоза 67 дней, этаноловый гепатоз (ЭГз), этаноловый фиброз (ЭФ), этаноловый цирроз (ЭЦ). Оценивали состояние центральной гемодинамики, вегетативной регуляции сердечным ритмом, морфологические изменения в сердце.

Результаты исследований и их обсуждение. Этаноловое повреждение привело к нарушению вегетативной регуляции сердечного ритма, гемодинамики и морфологическим изменениям, что зависело от моделируемой патологии и эмоциональности крыс. ЭГ привел к увеличению вариационного размаха, изменению кровенаполнения, периферического сопротивления сосудов, более выраженных у ВЭ. У ВЭ при ЭГз увеличилась мода, уменьшилась амплитуда моды, при ЭФ и ЭЦ уменьшилась мода, были более выражены морфологические изменения. У НЭ при ЭГз увеличилась мода, при ЭФ уменьшился вариационный размах, были более выражены компенсаторные гемодинамические изменения.

Этаноловое повреждение организма у крыс приводит к нарушению вегетативной регуляции сердечного ритма и гемодинамики. Острый этаноловый гепатит приводит к активации вагусных воздействий на сердечную деятельность, нарушению кровонаполнения, увеличению периферического сопротивления сосудов. Дисфункциональные изменения центральной гемодинамики и морфологические изменения выражены больше у ВЭ животных. При этаноловом гепатозе уменьшаются симпатичные регуляторные влияния на сердце. При этаноловых фиброзе и циррозе печени у ВЭ крыс растут симпатичные влияния, при фиброзе у НЭ уменьшаются вагусные. При этом компенсаторные гемодинамические изменения больше выражены у НЭ, а морфологические - у ВЭ.
\end{abstract}

Ключевые слова: этанол; гепатит; гепатоз; фиброз; цирроз; сердце; крысы; вегетативная нервная система; центральная гемодинамика. 